\title{
Ice thickness distribution and volume estimation of Burqin Glacier No. 18 in the Chinese Altay Mountains
}

\author{
JIN Shuang $^{1,2}$, LI Zhongqin ${ }^{2 *}$, WANG Zemin ${ }^{1 *}$, WANG Feiteng ${ }^{2}$, XU Chunhai ${ }^{2}$, AI Songtao ${ }^{1}$ \\ ${ }^{1}$ Chinese Antarctic Center of Surveying and Mapping, Wuhan University, Wuhan 430079, China; \\ ${ }^{2}$ State Key Laboratory of Cryosphere Science/Tianshan Glaciological Station, Northwest Institute of Eco-Environment and \\ Resources, Chinese Academy of Sciences, Lanzhou 730000, China
}

\begin{abstract}
Information on the thickness distribution and volume of glacier ice is highly important for glaciological applications; however, detailed measurements of the ice thickness of many glaciers in the Chinese Altay Mountains remain lacking. Burqin Glacier No. 18 is a northeast-orientated cirque glacier located on the southern side of the Altay Mountains. This study used PulseEKKO ${ }^{\circledR}$ PRO 100A enhancement ground-penetrating radar (GPR) to survey the ice thickness and volume of Burqin Glacier No. 18 in summer 2018. Together with GPR surveying, spatial distributed profiles of the GPR measurements were concurrently surveyed using the real-time kinematic (RTK) global navigation satellite system (GNSS, Unistrong E650). Besides, we used QuickBird, WorldView-2, and Landsat TM to delineate accurate boundary of the glacier for undertaking estimation of glacier ice volume. GPR measurements revealed that the basal topography of profile B1-B2 was flat, the basal topography of profile C1-C2 presented a V-type form, and the basal topography of profile D1-D2 had a typical U-type topographic feature because the bedrock near the central elevation of the glacier was relatively flat. The longitudinal profile A1-A2 showed a ladder-like distribution. Glacier ice was thin at the terminus and its thickness increased gradually from the elevation of approximately $2620 \mathrm{~m}$ a.s.l. along the main axis of the glacier tongue with an average value of $80( \pm 1) \mathrm{m}$. The average ice thickness of the glacier was determined as $27( \pm 2) \mathrm{m}$ and its total ice volume was estimated at $0.031( \pm 0.002) \mathrm{km}^{3}$. Interpretation of remote sensing images indicated that during 19892016, the glacier area reduced from 1.30 to $1.17 \mathrm{~km}^{2}$ (reduction of $0.37 \% / \mathrm{a}$ ) and the glacier terminus retreated at the rate of $8.48 \mathrm{~m} / \mathrm{a}$. The mean ice thickness of Burqin Glacier No. 18 was less than that of the majority of other observed glaciers in China, especially those in the Qilian Mountains and Central Chinese Tianshan Mountains; this is probably attributable to differences in glacier type and climatic setting.
\end{abstract}

Keywords: glacier ice thickness; glacier ice volume; glacier area; ground-penetrating radar; Bayesian kriging method mountain glacier

Citation: JIN Shuang, LI Zhongqin, WANG Zemin, WANG Feiteng, XU Chunhai, AI Songtao. 2020. Ice thickness distribution and volume estimation of Burqin Glacier No. 18 in the Chinese Altay Mountains. Journal of Arid Land, 12(6): 905-916. https://doi.org/10.1007/s40333-020-0083-9

\section{Introduction}

Information on the ice thickness distribution and ice volume of mountain glaciers is very important in assessment of the contribution of glaciers to freshwater resources and sea level rise (Farinotti et

\footnotetext{
*Corresponding author: LI Zhongqin (E-mail: lizq@lzb.ac.cn); WANG Zemin (E-mail: zmwang@whu.edu.cn) Received 2020-06-03; revised 2020-11-17; accepted 2020-11-25

(C) Xinjiang Institute of Ecology and Geography, Chinese Academy of Sciences, Science Press and Springer-Verlag GmbH Germany, part of Springer Nature 2020
} 
al., 2019). Measurements of glacier ice thickness are an important prerequisite both for projections of glacier hydrology and for modeling glacier dynamics (Gabbi et al., 2012). Glaciers in many regions have been studied comprehensively using remote sensing methods (Paul et al., 2004; Pfeffer et al., 2014; Sakai, 2019) and in situ measurements (Ma et al., 2010; Wang et al., 2016); however, owing to logistical challenges, it is rare for ice thickness surveys to be conducted (Farinotti et al., 2017; Kutuzov et al., 2018). Hence, several approaches have been developed to determine the ice thickness distribution and total ice volume of glaciers. Statistical volume-area scaling is one of the simplest approaches used to estimate glacier ice volume, but it is subject to considerable uncertainty because the relationship between the ice area and ice volume of a glacier does not account for the surface geometry and local climate of individual glaciers (Meier et al., 2007; Huss and Farinotti, 2012). Moreover, the method cannot provide details of certain physical parameters of a glacier, e.g., glacier surface/bedrock topography and glacier ice thickness, which are important for modeling the dynamic processes of glaciers (Andreassen et al., 2015).

Ground-penetrating radar (GPR) has become a well-established tool with which to survey glacier ice thickness owing to the simplicity of its field implementation and ease of data processing in comparison with other geophysical techniques (Binder et al., 2009). The principle of GPR is to register reflections of electromagnetic waves from internal features of glacier ice and from bedrock. The application of GPR is widespread in the field of glaciology (e.g., Binder et al., 2009; Fischer and Kuhn, 2013; Kutuzov et al., 2018) and following recent rapid advances in GPR technology, previous studies have used novel radar equipment for detection of glacier ice thickness (Ma et al., 2010; Wang et al., 2016).

To the best of our knowledge, measurements of the ice thickness of glaciers in China have focused primarily on the Tianshan Mountains, Qilian Mountains, and Tibetan Plateau (Wang et al., 2009; Li et al., 2012; Zhu et al., 2014; Wang et al., 2016a; Kutuzov et al., 2018). Measurements of the ice thickness and estimates of the ice volume of glaciers in the Chinese Altay Mountains have not been conducted; only information on the ice volume of the Muz Taw Glacier in the adjoining mountains (Sawir) has been reported. However, glaciers in this region are characterized by low elevation and high latitude, and they are affected by the westerly circulation during the summer months and by the Siberian High in winter and spring (Zhang et al., 2016). Consequently, the change processes of glaciers in the Chinese Altay Mountains are different from those of other glaciers in western China, which means that obtaining information on the ice thickness distribution and ice volume of glaciers in this region is highly important. Hence, the purpose of this study was to both determine details of the ice thickness distribution and estimate the ice volume of Burqin Glacier No. 18 based on measured GPR data and differential global navigation satellite system (GNSS) data.

\section{Study area}

The Altay Mountains extend over 2000 km spanning China, Kazakhstan, Russia, and Mongolia. According to the latest version of the Randolph Glacier Inventory (v6.0), the mountains contain 2243 glaciers that have a total area of $1135 \mathrm{~km}^{2}$ (RGI Consortium, 2017). The Chinese Altay Mountains are the southern slopes of the middle section of the mountain range, extending to the Russian territory in the northwest, the western parts of Mongolia in the east, and the Junggar Basin in the south. The Chinese Altay Mountains extend for more than $500 \mathrm{~km}$, and the highest peak is the Youyi Peak (4374 $\mathrm{m}$ a.s.l.). Unlike the glaciers in other mountains of China that are influenced by the monsoon climate, glaciers in this region are characterized by higher latitude and lower elevation, and they are affected by the alternation of westerly circulation and the Arctic Ocean air mass. The Altay Mountains are the runoff formation and collection areas of the Ertix River and the Ulungur River system, which is a strategic water reserve area for the Altay region and also the northern Xinjiang region. In the Altay Mountains, manifestation of climate change is very notable with the fastest temperature increase in China, and the related changes in regional glaciers, snow, and frozen soil and the subsequent hydrological effects are substantial. Changes in regional water resources not only threaten the sustainable development of oases but also affect the distribution of 
the water resources between China and its neighboring countries.

The Second Chinese Glacier Inventory (SCGI) stated that there were 273 glaciers in the Chinese Altay Mountains with a combined area of $178.78 \mathrm{~km}^{2}$ until 2014 (Guo et al., 2015). During 1960-2009, the shrinkage of glacier area and the reduction in glacier numbers were $29.82 \%$ and $36.91 \%$, respectively, i.e., higher than reported for the glaciers in the Chinese Tianshan Mountains and Qilian Mountains (Yao et al., 2012; Xing et al., 2017; Sun et al., 2018). Burqin Glacier No. $18\left(49^{\circ} 04^{\prime} 03^{\prime \prime}-49^{\circ} 04^{\prime} 41^{\prime \prime} \mathrm{N}, 87^{\circ} 26^{\prime} 15^{\prime \prime}-87^{\circ} 27^{\prime} 51^{\prime \prime} \mathrm{E}\right.$; Fig. 1) is a northeast-oriented cirque glacier located on the southern side of the Altay Mountains. In 2016, it covered an area of $1.17 \mathrm{~km}^{2}$ and extended in elevation from 2589 to $3273 \mathrm{~m}$ a.s.l., based on visual interpretation of WorldView-2 satellite imagery. The glacier is relatively flat (mean slope: approximately $18.5^{\circ}$ ) with no debris cover. Burqin Glacier No. 18 can be classified as a subcontinental glacier with accumulation in winter and strong ablation during summer (Shi, 2008).

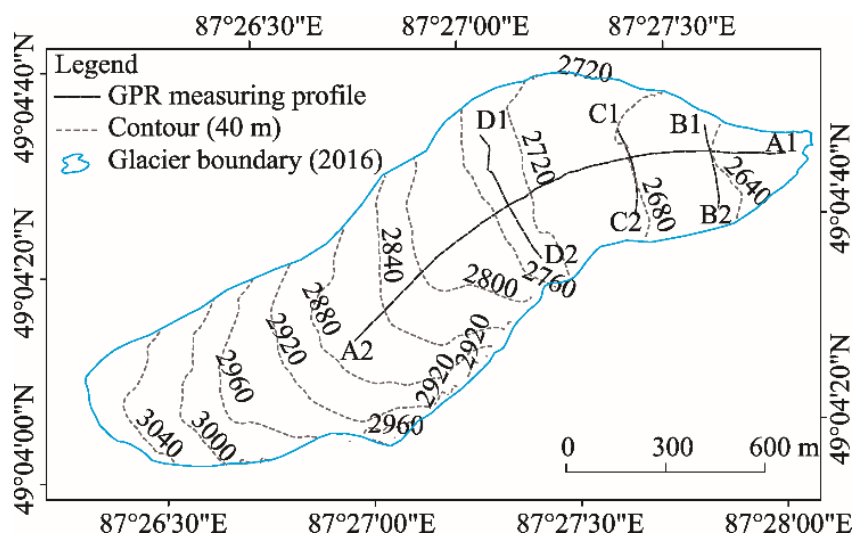

Fig. 1 Overview of Burqin Glacier No. 18 and ground-penetrating radar (GPR) measuring profiles of the glacier in 2018. The blue line is the glacier boundary in 2016 as derived from WorldView-2 image. A1-A2, longitudinal profile; B1-B2, C1-C2, and D1-D2, transverse profiles.

\section{Data and methods}

\subsection{PulseEKKO ${ }^{\circledR}$ PRO 100A enhancement GPR system}

The PulseEKKO ${ }^{\circledR}$ PRO 100A enhancement GPR (Sensors and Software Inc., Mississauga, Canada) transmitting antenna sends high-frequency short-pulse electromagnetic waves into the ground, which are returned after encountering an underground stratum or target body with electrical difference and received by the receiving antenna. The path, electromagnetic field strength, and waveform of the waves change when they pass through a medium with varied electrical and geometrical characteristics. Thus, a two-dimensional (2-D) radar image can be acquired by processing and analyzing the radar waves received by the receiving antenna. The grayscale or color form of the processed image reveals the vertical section of the underground body, which can be used to determine the spatial location of an underground interface or geological body. It was easy for us to identify the location of the ice-rock interface in the derived GPR image because of the obvious difference in the dielectric properties between the glacier ice and the bedrock, and thus the glacier thickness at each GPR survey point could be obtained. The PulseEKKO ${ }^{\circledR}$ PRO 100A enhancement GPR provides an unparalleled performance across a broad range of frequencies (12.5-1000.0 MHz) for applications in glaciology with high-resolution, geotechnical investigations, and concrete imaging.

\subsection{In situ measurements}

Ice thickness of Burqin Glacier No. 18 was measured using the PulseEKKO ${ }^{\circledR}$ PRO $100 \mathrm{~A}$ enhancement GPR in summer 2018. This type of radar is used extensively in glaciological applications (e.g., Huai et al., 2015; Wang et al., 2016; Pieczonka et al., 2018). A common-offset 
geometry with point measuring mode was configured in the survey with the antenna set at 100 MHz. The transmitting and receiving antennas, separated by a distance of $4 \mathrm{~m}$, were arranged parallel to each other and perpendicular to the profiling direction. The stacking times of the traces were set as 32 to improve the signal-to-noise ratio, and then the 2-D radar images were generated. Larger coupling between the antennas can be expected with such a configuration. The relative error was reported to be approximately $1.2 \%$, i.e., within an acceptable accuracy range for glaciology (Sun et al., 2003). The power transmission of this type of antenna is directional, with most of the power directed downward in a plane perpendicular to the long axis of the antenna (Annan et al., 1975). Hence, the surveys were implemented with the antenna orientated perpendicular to the line of survey to ensure that the maximum power was transmitted in-line.

In conducting the GPR measurements, we tried to ensure that the longitudinal profile (A1-A2; Fig. 1) was along the main flow line of Burqin Glacier No. 18, and the transverse profiles (B1-B2, C1-C2, and D1-D2; Fig. 1) were perpendicular to the direction of the main flow line (Fig. 2). No in situ measurements were acquired in steep and high terrain. In addition to the GPR surveying, the spatially distributed GPR profiles were surveyed concurrently using GNSS (Unistrong E650) real-time kinematic data. The three-dimensional (3-D) GNSS coordinates were obtained in the Universal Transverse Mercator 45N coordinate system of the World Geodetic System 1984 (WGS84) ellipsoidal elevation datum. The horizontal and vertical accuracy of the real-time kinematic survey was reported to be within 1 and 2 cm, respectively (Wang et al., 2016; Xu et al., 2017).
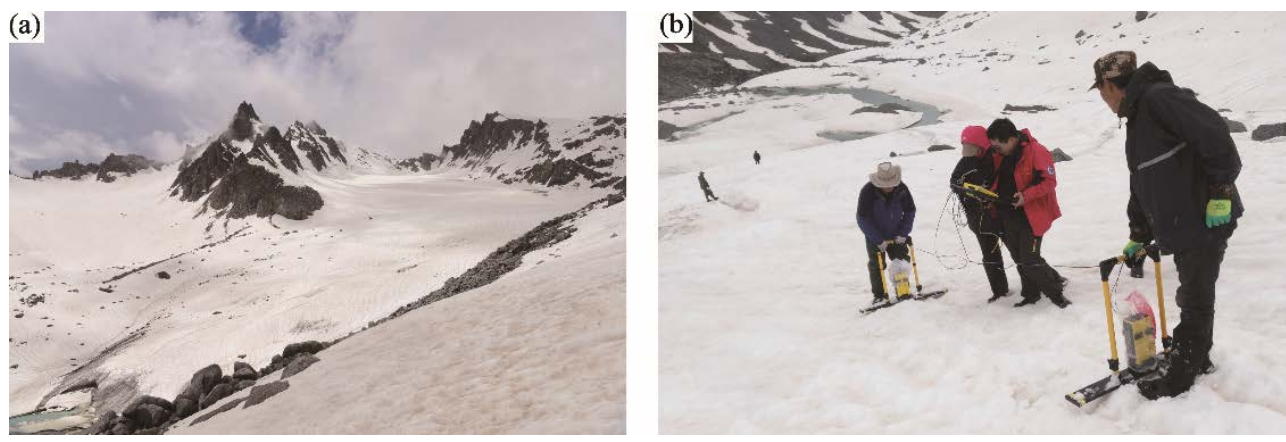

Fig. 2 Photos of Burqin Glacier No. 18 (a) and acquisition of GPR measurements on the longitudinal profile on the glacier (b)

\subsection{Remote sensing images}

QuickBird, WorldView-2, and Landsat TM satellite images were used to delineate an accurate boundary of Burqin Glacier No. 18. The selected images were acquired during the season of strong ablation without clouds and little seasonal snow. Specifically, two panchromatic remote sensing images from the commercial QuickBird (spatial resolution: $0.61 \mathrm{~m}$ ) and WorldView-2 (spatial resolution: $0.45 \mathrm{~m}$ ) satellites were acquired on 9 September 2002 and 24 August 2016, respectively; one Landsat TM satellite image (spatial resolution: $15.00 \mathrm{~m}$ ) was acquired on 25 August 1989, which is available from the following website: https://earthexplorer.usgs.gov. Additionally, the Shuttle Radar Topography Mission (SRTM) C-band digital elevation model (DEM) was used to reconstruct the glacier basal topography. During the single-pass of the interferometric synthetic aperture radar SRTM in February 2000, the SRTM C-band DEM was generated from radar interferometry with a spatial resolution of 3 arcseconds $(90 \mathrm{~m})$, covering approximately $80 \%$ of the earth's surface. The DEM is freely available (https://earthexplorer.usgs.gov) for scientific research with the coordinate system of the WGS84 defined as the 1996 Earth Gravitational Model geoid. The relative and absolute vertical accuracy is specified as 6 and $16 \mathrm{~m}$, respectively (Rabus et al., 2003).

\subsection{Radar data postprocessing}

3.4.1 Retrieval of ice thickness

Postprocessing of the GPR data was performed using EKKO_View Deluxe software (professional 
version). On the 2-D radar image, glacier ice thickness $h(\mathrm{~m})$ point data derived from the vertical axis radar wave two-way travel time were determined using the following equation (He et al., 2004):

$$
h=\frac{\sqrt{v^{2} t^{2}-x^{2}}}{2},
$$

where $v(\mathrm{~m} / \mathrm{ns})$ is the velocity of the radar signal in the glacier; $t$ (ns) is the two-way travel time of the radar wave; and $x(\mathrm{~m})$ is the distance between the antennas. For mountain glaciers, the propagation velocity is in the range of $0.167-0.171 \mathrm{~m} / \mathrm{ns}$, which is in accord with values reported previously, e.g., $0.167 \mathrm{~m} / \mathrm{ns}$ by Glen and Paren (1975), $0.1685 \mathrm{~m} / \mathrm{ns}$ by Robin (1975), and 0.168 $\mathrm{m} / \mathrm{ns}$ by Narod and Clarke (1994).

The upper elevations of Burqin Glacier No. 18 are steep and in situ measurements of glacier ice thickness are not possible. Therefore, information on the upper parts of the glacier were determined using the perfect-plasticity assumption for rheology of Nye (1951), which can be calculated from the surface slope using the following equation (Cuffey and Paterson, 2010):

$$
h=\tau_{0} / \rho \mathrm{g} \sin \alpha,
$$

where $\tau_{0}(\mathrm{kPa})$ is the basal shear stress; $\rho\left(\mathrm{kg} / \mathrm{m}^{3}\right)$ is the glacier ice density $\left(900 \mathrm{~kg} / \mathrm{m}^{3}\right)$; $\mathrm{g}$ is the acceleration of gravity $\left(9.81 \mathrm{~m} / \mathrm{s}^{2}\right)$; and $\alpha\left({ }^{\circ}\right)$ is the glacier surface slope in radians. Binder et al. (1970) assumed that a constant $\tau_{0}$ is suitable for estimates of mountain glacier ice volume. In this study, we took the value $\tau_{0}$ along the main streamlines of $100 \mathrm{kPa}$ (Schlosser, 1997). Detailed comparison of the modeled and in situ measurements of ice thickness along profile A1-A2 revealed reasonable agreement at most points $\left(R^{2}=0.88\right)$. The absolute difference between the two sets of ice thickness data was in the range of 2.17-21.33 m (mean: $8.44 \mathrm{~m}$ ). It should be noted that the coarse and outdated SRTM C-band DEM for glacier surface slope calculation also increases the uncertainty of modeled ice thickness because Equation 2 is dependent on the surface slope of the glacier. Given the uncertainty of the GPR measurements and numerical calculations, this represents a promising result.

\subsubsection{Ice thickness interpolation}

Interpolating ice thickness point data can generate glacier-wide ice thickness. Generally, observed GPR data are interpolated using probabilistic approaches such as inverse distance weighting, local polynomial, and kriging interpolation methods. Previous studies suggested that all methods yield different correlations between interpolated and observed ice thickness, and that kriging method exhibits a better performance than other methods for ice thickness interpolation (Wang et al., 2014a; Huai et al., 2015; Pieczonka et al., 2018). The basis of kriging interpolation is the variogram, which characterizes the spatial variability of the studied characteristic. Sill, range, and nugget are the three important variogram parameters defining geostatistical spatial correlation. This study used the empirical Bayesian kriging method for ice thickness interpolation using ArcGIS Geostatistical Analyst, which considers the semivariogram model errors by automated subsetting of the observations and performs numerous repeated semivariogram model calculations. Kutuzov et al. (2018) demonstrated that the empirical Bayesian kriging method is a powerful tool for GPR measurements as it can effectively compensate for the flaw of cross-validation and underestimation of the interpolation error for the non-uniform ice thickness point data distribution.

\subsection{Error estimation}

Determination of ice thickness distribution and estimation of ice volume of glaciers depend on errors in the GPR point measurements and the interpolation procedure. We evaluated each of these components separately.

\subsubsection{Point ice thickness measurement}

In our fieldwork, we configured the value of the propagation velocity of the radar wave as 0.169 $\mathrm{m} / \mathrm{ns}$ and calculated the corresponding relative error using the following equation (Ma et al., 2010):

$$
\frac{\mathrm{d} h}{h}=\frac{\mathrm{d} v}{2 v}=1.2 \% \text {. }
$$


Hence, the relative error of the measurement system used in this study was $1.2 \%$. Through comparison of glacier ice thicknesses derived from GPR survey and drilled boreholes, Sun et al. (2003) estimated a survey error to be $<2.0 \%$. Actually, the uncertainty of GPR-measured ice thickness can be determined by the accuracy of the instrument system and the properties of the ice and bedrock (Fischer, 2009). The first factor was calculated using Equation 3. The second factor was more difficult to quantify and it can have considerable effect on ice thickness estimation (Wang et al., 2014a). The internal structure of glacier ice (e.g., crevasses, inhomogeneities, terrain, and roughness of the bedrock) can increase the uncertainty; however, the lack of in situ measured thickness data limited quantification of the relevant uncertainties.

\subsubsection{Ice thickness interpolation}

The error stems mainly from extrapolation of observed point thickness to unmeasured areas and dramatic variations in ice thicknesses over short distances. The width of Burqin Glacier No. 18 is reasonably narrow and the median-lower parts of the glacier were well covered by profiles (Fig. 1). Ice thickness along the main flow line at higher elevations was calculated using Equation 2, and the variation of ice thickness over short distances was considered not significant. Hence, errors related to ice thickness interpolation were deemed small, i.e., we conservatively assumed that the uncertainty of ice thickness interpolation was approximately 6.0\% (Wang et al., 2014b).

\section{Results}

\subsection{Characteristics of ice thickness along transverse and longitudinal profiles}

Processed radargrams for Burqin Glacier No. 18 after elevation calibration, which illustrated the detailed characteristics of the transverse changes in ice thickness and elevation of the glacier surface and bedrock, are shown in Figure 3. Basal reflections can be seen clearly on profiles B1-B2, C1-C2, and D1-D2, and glacier ice thickness was generally greater in the center of the
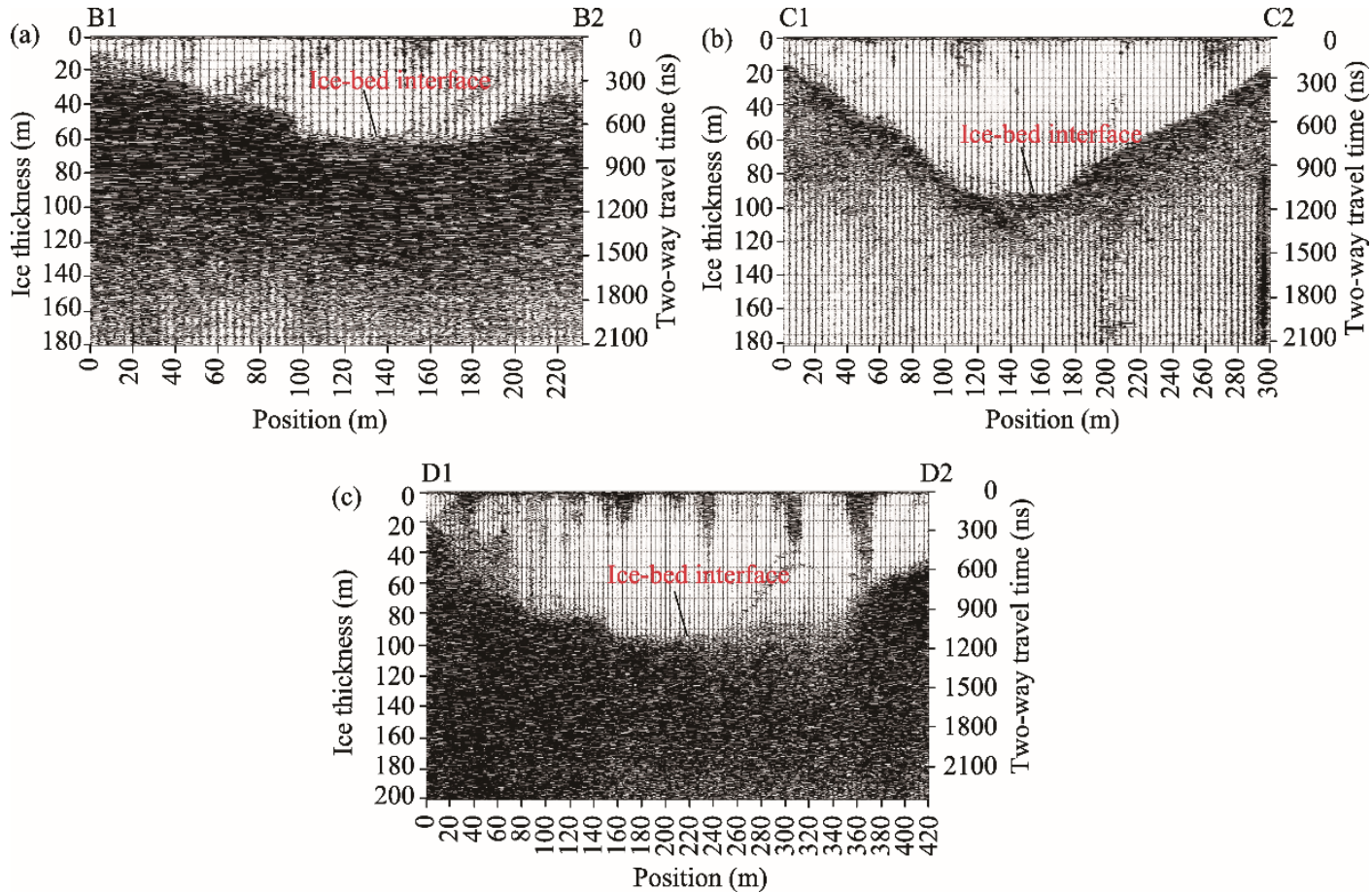

Fig. 3 Processed radargrams showing transverse section profiles B1-B2 (a), C1-C2 (b), and D1-D2 (c) of Burqin Glacier No. 18. The $x$-axis indicates the distance from the beginning point of the GPR survey. The left and right vertical axes of each panel in the figure indicate glacier ice thickness and two-way travel time of the electromagnetic radar wave, respectively. 
profiles than towards the laterals. Based on the three observed ice thickness profiles, we estimated the mean ice thickness at approximately $61( \pm 1) \mathrm{m}$ and determined the maximum thickness (found in the center of profile D1-D2) as $98( \pm 1) \mathrm{m}$. In profile B1-B2, the basal topography was shown as reasonably flat and the glacier ice was relatively thin with the maximum value of $60( \pm 1) \mathrm{m}$ (Fig. $3 a)$, which might reflect the position of this profile at the glacier tongue. In profile $\mathrm{C} 1-\mathrm{C} 2$, the glacier bedrock terrain presented a V-type form with the maximum ice thickness of $94( \pm 1) \mathrm{m}$ (Fig. 3b). In the upper elevations, profile D1-D2 exhibited a typical U-type characteristic because the bedrock near the central elevation of the glacier was relatively flat (Fig. 3c).

Figure 4 shows a processed radargram of the longitudinal profile A1-A2. The measured ice thickness varied along the direction of the ice flow line from the glacier terminus to an elevation of approximately $2850 \mathrm{~m}$ a.s.l., with a mean value of $80( \pm 1) \mathrm{m}$ (Fig. 4a). Visual inspection revealed a ladder-like pattern to the form of the basal topography. Maximum ice thickness in the longitudinal section occurred at elevations above $2750 \mathrm{~m}$ a.s.l. (Fig. 4b). Generally, the ice was thin at the glacier terminus and its thickness increased gradually from the elevation of $2620 \mathrm{~m}$ a.s.l. along the main flow line of the glacier.
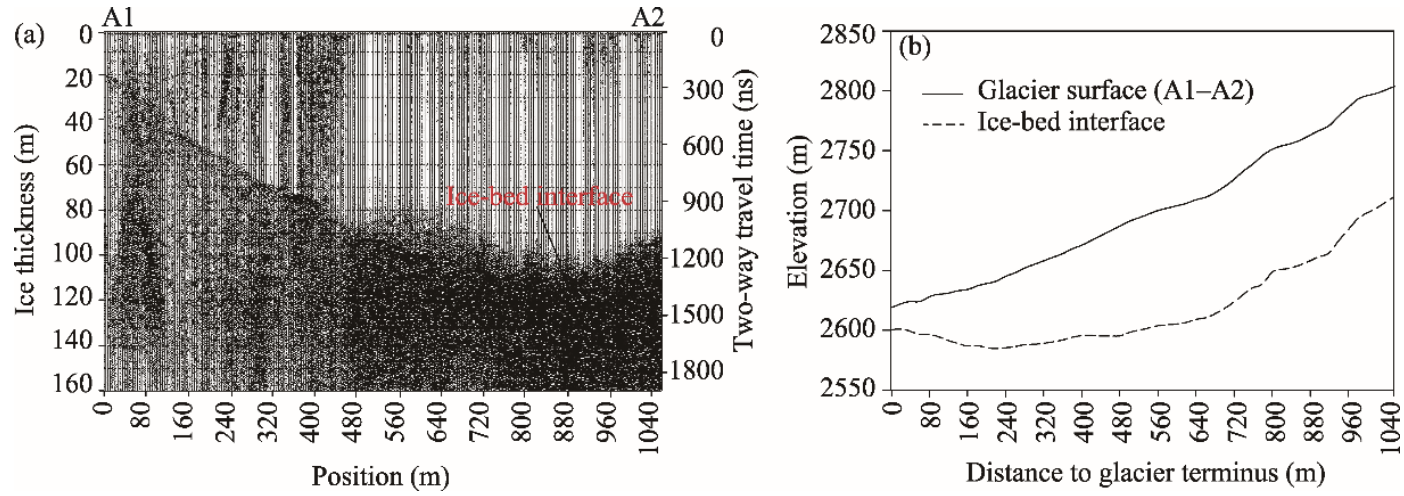

Fig. 4 Processed radargram showing the longitudinal section profile A1-A2 of Burqin Glacier No. 18 (a), and the longitudinal section profile A1-A2 and ice-bed interface in the left panel being calibrated by elevation and ice thickness (b)

\subsection{Glacier area change and ice volume estimation}

Glacier area is a crucial input datum for undertaking estimation of glacier ice volume. Results suggested that the area of Burqin Glacier No. 18 was $1.30 \mathrm{~km}^{2}$ in 1989, $1.25 \mathrm{~km}^{2}$ in 2002, and 1.17 $\mathrm{km}^{2}$ in 2016. Glacier area shrinkage was mainly attributed to terminus retreat (Fig. 5). Glacier area reduced at a rate of 0.30\%/a during 1989-2002 and 0.46\%/a during 2012-2016, with an average shrinkage rate of $0.37 \%$ /a during the entire period (1989-2016). The retreat of the glacier terminus in the flow line direction during 1989-2016 has been determined as $229 \mathrm{~m}$, with an average retreat rate of $8.48 \mathrm{~m} / \mathrm{a}$. Observations of the glacier terminus suggested an average retreat rate of $7.50 \mathrm{~m} / \mathrm{a}$ during 1989-2002 and 9.50 m/a during 2002-2016, indicating that accelerated terminus retreat has occurred in the recent decades. Additionally, a glacial lake was observed in 2016 following strong ablation (Fig. 5b and c).

The empirical Bayesian kriging method was used to interpolate the GPR-measured data over the entire glacier area to generate a color-coded spatial distribution of glacier ice thickness on a 10-m grid (Fig. 6). The distribution of ice thickness was characterized by thin ice around the glacier margins and upper elevations, and thick ice in the lower central area of the glacier, consistent with the spatial distribution of ice thickness of Urumqi Glacier No. 1 (Wang et al., 2016). The mean glacier-wide thickness was calculated at approximately $27( \pm 2) \mathrm{m}$ by assuming that the marginal ice thickness of the glacier (including nunataks and rock outcrops) was zero. Thus, glacier ice volume was calculated as approximately $0.031( \pm 0.002) \mathrm{km}^{3}$ by multiplying the glacier area and average thickness, which was equal to the water equivalent of $0.028( \pm 0.002) \mathrm{km}^{3}$ assuming ice density of $900 \mathrm{~kg} / \mathrm{m}^{3}$. 

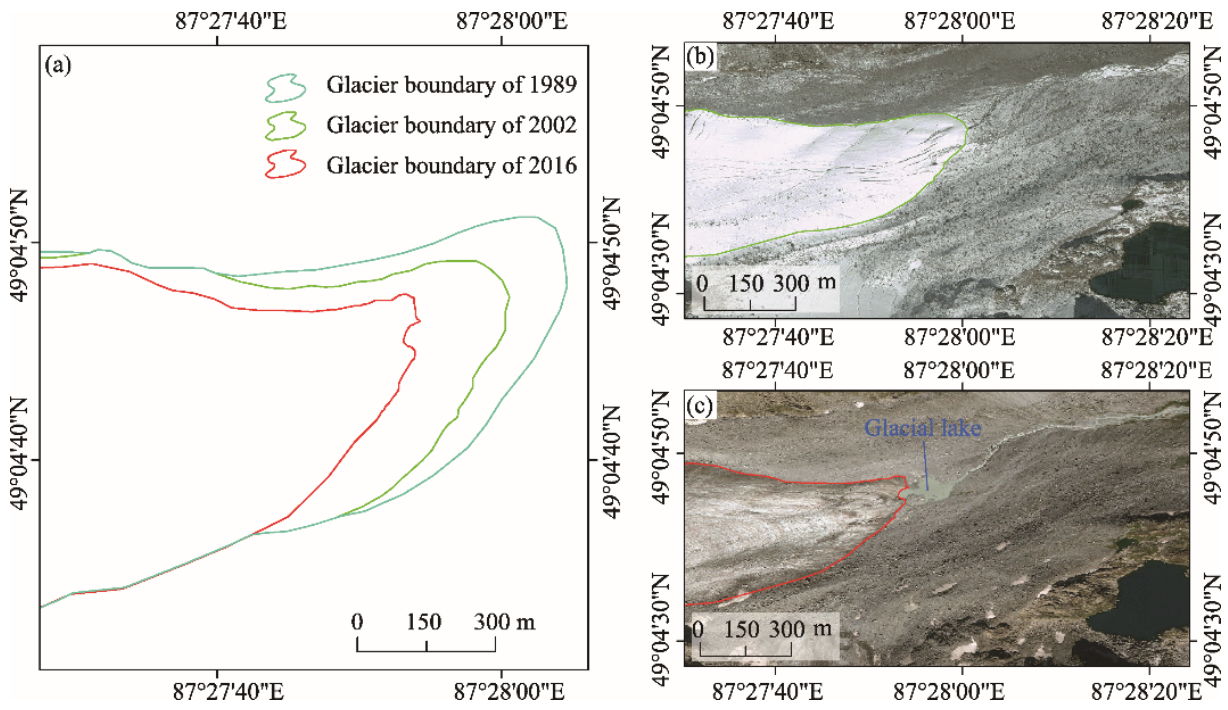

Fig. 5 Temporal variation of terminus of Burqin Glacier No. 18 during 1989-2016 (a), and images showing the boundary of Burqin Glacier No. 18 in 2002 (b) and 2016 (c). The background images in 2002 and 2016 are from the QuickBird and WorldView-2 satellites, respectively.

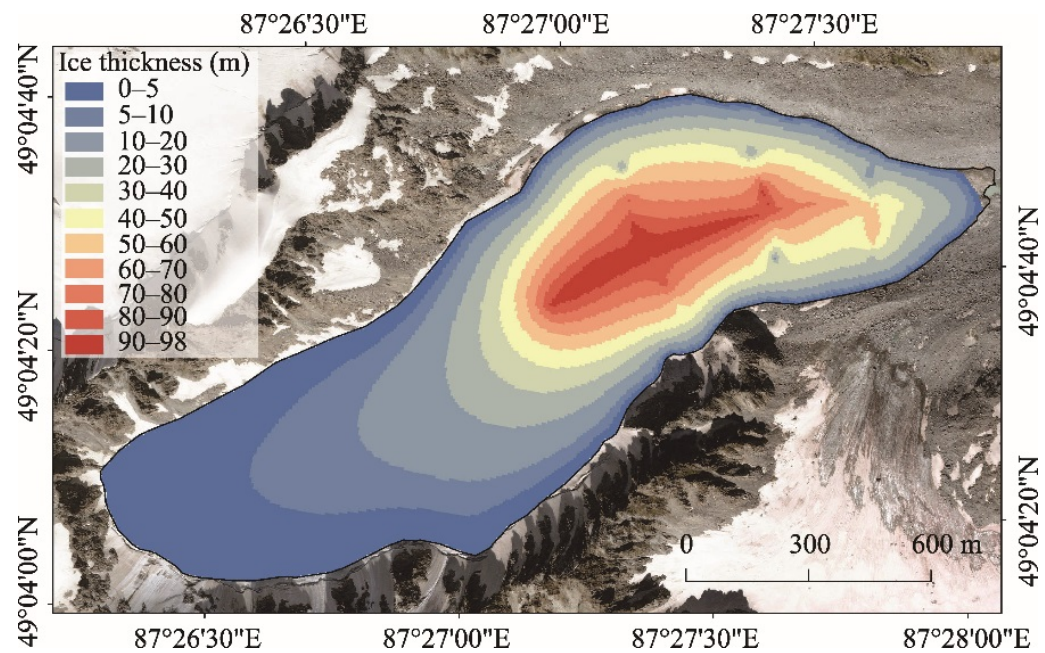

Fig. 6 Spatial distribution of interpolated ice thickness. The background image is from the WorldView-2 satellite.

\subsection{Glacier basal topography}

The 10-m-grid DEM of the glacier bedrock was extracted by subtracting the ice thickness distribution data from the SRTM C-band DEM, and then contours of the bedrock topography at 40-m intervals were delineated (Fig. 7). The reconstruction was predicated on the assumptions that ice thickness was zero at the glacier margin and that ice thickness in crevassed zones was lower than that of surrounding areas exhibiting the same surface slope without crevasses (Wang et al., 2014a). We used modeled ice thicknesses for the unmeasured high elevation areas and the performance of the modeled results was considered satisfactory. The topography at the glacier terminus was irregular, showing areas of pronounced over deepening; however, a regular pattern was revealed in the upper parts of the glacier, which agreed well with the GPR profile thickness data shown in Figure 4 and is similar to the results obtained for other glaciers, e.g., Urumqi Glacier No. 1 (Sun et al., 2003) and Glacier No. 4 of Sigong River (Wang et al., 2014a) in the Tianshan Mountains, China. Additionally, the bedrock terrain of Burqin Glacier No. 18 was shown to undulate more than the surface terrain. 


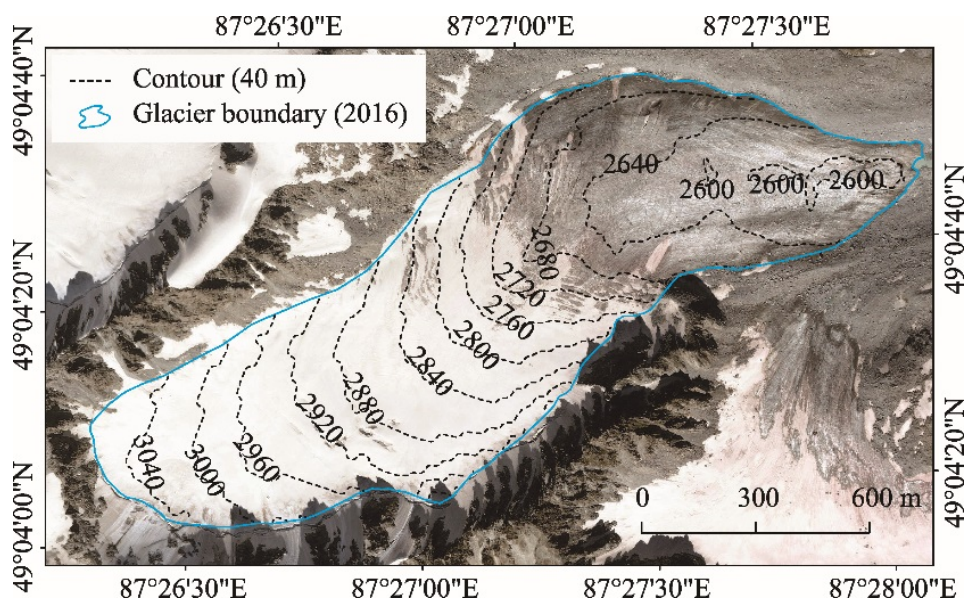

Fig. 7 Basal topography of Burqin Glacier No. 18 (contour interval: $40 \mathrm{~m}$ ). The background image is from the WorldView-2 satellite.

\section{Discussion}

\subsection{Quality of GPR measurements and glacier ice volume}

The performance of electromagnetic waves in penetrating the glacier and the processing of the radar images to represent the ice-bedrock interface together represent the most important factors in detecting glacier ice thickness and revealing changes of basal topography. The radargrams shown in Figures 3 and 4 provided clear indication of the location of the ice-bedrock interface, indicating that the GPR instrument, methodology, survey parameter settings, and profile layout adopted in this study were reasonable. In the 2-D radargrams, we calculated ice thickness based on the two-way travel time of the electromagnetic waves, i.e., the quality of the GPR-measured ice thickness data depended on the accuracy of the two-way travel time and radar signal speed. The surveying interval of the radar data was configured as $0.8 \mathrm{~ns}$. Therefore, the time error of the radar measurements did not exceed $0.8 \mathrm{~ns}$, meaning that it could be ignored completely. The speed of electromagnetic radar waves in glaciers is in the range of $0.167-0.171 \mathrm{~m} / \mathrm{ns}$, and the corresponding error in terms of ice thickness is $<2.0 \%$. Thus, the GPR instrument yielded convincing results and the quality of the ice thickness measurements was considered reliable. Nevertheless, uncertainties in extrapolating observed point thicknesses to unmeasured areas (e.g., areas of precipitous terrain and crevasses) could potentially reduce the quality of the estimation of glacier ice volume. This study used the Equation 2 proposed by Nye (1951) to calculate glacier ice thickness in unmeasured high elevation areas, which reduced the extrapolated uncertainties. To gain added value in relation to unmeasured areas, we might consider performing helicopter-borne dual-polarization GPR surveys in the future, which is a technique that has been used successfully to reconstruct glacier beds in the Swiss Alps (Langhammer et al., 2019).

\subsection{Comparison with previous results}

Measurements of glacier ice thickness in western China are performed rarely because obtaining field measurements is a laborious, time-consuming, and potentially dangerous activity; consequently, the thickness of the ice in only a small number of glaciers has been measured using GPR (GlaThiDa Consortium, 2019). Table 1 lists the mean ice thickness obtained for selected glaciers in different Chinese mountain areas. The mean value is in the range of 26.0-60.5 m; thus, the corresponding value of Burqin Glacier No. 18 is lower than that of the majority of the other glaciers, especially those in the Qilian Mountains and Central Chinese Tianshan Mountains. However, the mean value of Burqin Glacier No. 18 is close to that of Kangwure Glacier in the Central Himalayas, Meikuang Glacier in the Kunlun Mountains, and Sigong River Glacier No. 4 in the Tianshan Mountains. This might be related to glacier basal topography and climatic setting. In addition, Table 1 shows that the observed change rate of glacier area is greatest in the Central 
Himalayas, followed by Nyainqêntanglha Mountains and the Sawir Mountains; the rate of change in the Central Chinese Tianshan Mountains is smallest. The change rate of area of Burqin Glacier No. 18 is close to that of glaciers in the Central Chinese Tianshan Mountains, which might reflect the fact that the change rate of this small cirque glacier is controlled mainly by thickness thinning (Wang et al., 2016).

Table 1 Comparison of the mean ice thickness and area change rate for selected glaciers in different Chinese mountain areas

\begin{tabular}{|c|c|c|c|c|c|c|}
\hline Mountain & Glacier & $\begin{array}{c}\text { Mean ice } \\
\text { thickness (m) }\end{array}$ & $\begin{array}{l}\text { Survey } \\
\text { year }\end{array}$ & $\begin{array}{c}\text { Change rate } \\
\text { of area } \\
(\% / a)\end{array}$ & Period & Source \\
\hline $\begin{array}{l}\text { Nyainqêntanglha } \\
\text { Mountains }\end{array}$ & Gurenhekou Glacier & 36.0 & 2007 & - & - & Ma et al. (2008) \\
\hline Central Himalayas & Kangwure Glacier & 26.4 & 2008 & -1.01 & 1974-2008 & Ma et al. (2010) \\
\hline Kunlun Mountains & Meikuang Glacier & 26.0 & 2015 & -0.42 & 1969-2015 & Li et al. (2018) \\
\hline $\begin{array}{l}\text { Karakorum } \\
\text { Mountains }\end{array}$ & Gani Glacier & 51.0 & 2018 & - & - & Jin and Tian (2019) \\
\hline $\begin{array}{l}\text { Nyainqêntanglha } \\
\text { Mountains }\end{array}$ & Zhadang Glacier & 38.1 & 2011 & -0.68 & 1970-2010 & Zhu et al. (2014) \\
\hline Qiangtang Plateau & Qiangtang Glacier No. 1 & 51.0 & 2013 & - & - & Zhu et al. (2014) \\
\hline $\begin{array}{l}\text { Eastern Tianshan } \\
\text { Mountains }\end{array}$ & Yushugou Glacier No. 6 & $50.0^{*}$ & 2011 & - & - & Wang et al. (2015) \\
\hline $\begin{array}{l}\text { Eastern Tianshan } \\
\text { Mountains }\end{array}$ & Sigong River Glacier No. 4 & 27.6 & 2009 & - & - & Wang et al. (2014a) \\
\hline $\begin{array}{c}\text { Central Tianshan } \\
\text { Mountains }\end{array}$ & Haxilegen Glacier No. 51 & 39.0 & 2010 & -0.23 & 1964-2010 & Wang et al. (2016a) \\
\hline $\begin{array}{c}\text { Central Tianshan } \\
\text { Mountains }\end{array}$ & Urumqi Glacier No. 1 & 44.5 & 2012 & -0.33 & 1962-2012 & Wang et al. (2016b) \\
\hline $\begin{array}{l}\text { Western Tianshan } \\
\text { Mountains }\end{array}$ & Qingbingtan Glacier No. 72 & $45.0^{*}$ & 2008 & -0.49 & 1964-2008 & Wang et al. (2017) \\
\hline Qilian Mountains & Bayi Glacier & 54.2 & 2006 & - & - & Wang et al. (2009) \\
\hline Sawir Mountains & Muz Taw Glacier & 60.5 & 2013 & -0.57 & 1977-2013 & Huai et al. (2015) \\
\hline Altay Mountains & Burqin Glacier No. 18 & 27.0 & 2018 & -0.37 & 1989-2016 & This study \\
\hline
\end{tabular}

Note: ${ }^{~}$ means that only the glacier tongue was considered; - donates no observed data.

\section{Conclusions}

This study used the PulseEKKO ${ }^{\circledR}$ PRO 100A enhancement GPR to monitor the ice thickness of Burqin Glacier No. 18 in the Chinese Altay Mountains. Our results suggested that the glacier thickness of the transverse profiles was generally thicker in the middle than toward the laterals. The survey revealed that the glacier has complex basal topography (i.e., U-type and V-type features). The area of Burqin Glacier No. 18 was $1.17 \mathrm{~km}^{2}$ in 2016, and its rate of shrinkage was $0.37 \%$ /a during 1989-2016. Glacier area shrinkage was attributed mainly to terminus retreat, and the average retreat rate was $8.48 \mathrm{~m} / \mathrm{a}$ over the entire study period. The average ice thickness of the glacier was estimated at approximately $27( \pm 2) \mathrm{m}$ and the glacier ice volume was estimated at $0.031( \pm 0.002)$ $\mathrm{km}^{3}$. The GPR instrument adopted in this study yielded convincing results, and the uncertainties of ice thickness interpolation were considered the main factors affecting the accuracy of the estimation of glacier ice volume. Nonetheless, this study only got one longitudinal and three transverse ice thickness measuring profiles, to improve the quality of ice thickness measurements, we recommend that helicopter-borne dual-polarization GPR surveys can be implemented in the future.

\section{Acknowledgements}

This research was supported by the Strategic Priority Research Program of the Chinese Academy of Sciences (XDA20020102, XDA20060201), the Second Tibetan Plateau Scientific Expedition and Research (STEP) Program (2019QZKK0201), the National Natural Science Foundation of China (International cooperation and exchange projects) (41761134093), and the National Natural Science Foundation of China (41771077). We are very grateful to the Tianshan Glaciological Station for field data collection. 


\section{References}

Andreassen L M, Huss M, Melvold K, et al. 2015. Ice thickness measurements and volume estimates for glaciers in Norway. Journal of Glaciology, 61(228): 763-775.

Annan A P, Waller W M, Strangway D W, et al. 1975. The electromagnetic response of a low-loss, 2-layer, dielectric earth for horizontal electric dipole excitation. Geophysics, 40(2): 285-298.

Binder D, Brückl E, Roch K H, et al. 2009. Determination of total ice volume and ice-thickness distribution of two glaciers in the Hohe Tauern region, Eastern Alps, from GPR data. Annals of Glaciology, 50(51): 71-79.

Cuffey K M, Paterson W S B. 2010. The Physics of Glaciers (Fourth Edition). Amsterdam: Academic Press, 469-475.

Farinotti D, Usselmann S, Huss M, et al. 2012. Runoff evolution in the Swiss Alps: projections for selected high-alpine catchments based on ENSEMBLES scenarios. Hydrological Processes, 26(13): 1909-1924.

Farinotti D, Huss M, Fürst J J, et al. 2019. A consensus estimate for the ice thickness distribution of all glaciers on Earth. Nature Geoscience, 12(3): 168-173.

Fischer A. 2009. Calculation of glacier volume from sparse ice-thickness data, applied to Schaufelferner, Austria. Journal of Glaciology, 55(191): 453-460.

Fischer A, Kuhn M. 2013. Ground-penetrating radar measurements of 64 Austrian glaciers between 1995 and 2010. Annals of Glaciology, 54(64): 179-188.

Gabbi J, Farinotti D, Bauder A, et al. 2012. Ice volume distribution and implications on runoff projections in a glacierized catchment. Hydrology and Earth System Sciences, 16(12): 4543-4556.

GlaThiDa Consortium. 2019. Glacier Thickness Database 3.0.1. World Glacier Monitoring Service, Zurich, Switzerland. [2019-03-12]. https://doi.org/10.5904/wgms-glathida-2019-03.

Glen J W, Paren J G. 1975. The electrical properties of snow and ice. Journal of Glaciology, 15(73): 15-38.

Guo W Q, Liu S Y, Xu J L, et al. 2015. The second Chinese glacier inventory: data, methods and results. Journal of Glaciology, 61(226): 357-372.

He M B, Sun B, Yang Y, et al. 2004. Ice thickness determination and analysis of no. 1 glacier at the source of Urumqi River, Tianshan by ground penetrating radar. Journal of East China Institute of Technology, 27(3): 235-339. (in Chinese)

Huai B J, Li Z Q, Wang F T, et al. 2015. Glacier volume estimation from ice-thickness data, applied to the Muz Taw glacier, Sawir Mountains, China. Environmental Earth Sciences, 74(3): 1861-1870.

Huss M, Farinotti D. 2012. Distributed ice thickness and volume of all glaciers around the globe. Journal of Geophysical Research: Earth Surface, 117(F04010), https://doi.org/10.1029/2012JF002523.

Jin S Q, Tian L D. 2019. Depth sounded by GPR and volume estimated of the Gani Glacier in Ngari Prefecture, Tibet. Journal of Glaciology and Geocryology, 41(3): 516-524. (in Chinese)

Kutuzov S, Thompson L G, Lavrentiev I, et al. 2018. Ice thickness measurements of Guliya ice cap, western Kunlun Mountains (Tibetan Plateau), China. Journal of Glaciology, 64(248): 977-989.

Langhammer L, Rabenstein L, Schmid L, et al. 2019. Glacier bed surveying with helicopter-borne dual-polarization ground-penetrating radar. Journal of Glaciology, 65(249): 123-135.

Li H L, Felix N, Li Z Q, et al. 2012. An extended "perfect-plasticity" method for estimating ice thickness along the flow line of mountain glaciers. Journal of Geophysical Research: Earth Surface, 117(F01020), https://doi.org/10.1029/2011JF002104.

Li Y N, Li Z, Wang N L. 2018. Ice thickness sounded by ground penetrating radar on the Meikuang Glacier in the Eastern Kunlun Mountains. Journal of Glaciology and Geocryology, 40(1): 38-46. (in Chinese)

Ma L L, Tian L D, Yang W, et al. 2008. Measuring the depth of Gurenhekou glacier in the south of the Tibetan plateau using GPR and estimating its volume based on the outcomes. Journal of Glaciology and Geocryology, 30(5): 783-788. (in Chinese)

Ma L L, Tian L D, Pu J C, et al. 2010. Recent area and ice volume change of Kangwure Glacier in the middle of Himalayas. Chinese Science Bulletin, 55(20): 2088-2096.

Meier M F, Dyurgerov M B, Rick U K, et al. 2007. Glaciers dominate eustatic sea-level rise in the $21^{\text {st }}$ century. Science, 317(5841): 1064-1067.

Narod B B, Clarke G K C. 1994. Miniature high-power impulse transmitter for radio-echo sounding. Journal of Glaciology, 40(134): 190-194.

Nye J F. 1951. The flow of glaciers and ice-sheets as a problem in plasticity. Proceedings of the Royal Society of London Series A, 207(1091): 554-572.

Paul F, Kääb A, Maisch M, et al. 2004. Rapid disintegration of Alpine glaciers observed with satellite data. Geophysical Research Letters, 31(21): 510-518.

Pfeffer W T, Arendt A A, Bliss A, et al. 2014. The Randolph Glacier Inventory: a globally complete inventory of glaciers. Journal 
of Glaciology, 60(221): 537-552.

Pieczonka T, Bolch T, Kröhnert M, et al. 2018. Glacier branch lines and glacier ice thickness estimation for debris-covered glaciers in the Central Tien Shan. Journal of Glaciology, 64(247): 835-849.

Rabus B, Eineder M, Roth A, et al. 2003. The shuttle radar topography mission — a new class of digital elevation models acquired by spaceborne radar. ISPRS Journal of Photogrammetry and Remote Sensing, 57(4): 241-262.

RGI Consortium. 2017. Randolph glacier inventory—a dataset of global glacier outlines: Version 6.0: technical report, global land ice measurements from space. Colorado, USA. Digital Media. https://doi.org/10.7265.

Robin G Q. 1975. Velocity of radio waves in ice by means of a bore-hole interferometric technique. Journal of Glaciology, 15(73): 151-159.

Sakai A. 2019. Brief communication: Updated GAMDAM glacier inventory over high-mountain Asia. The Cryosphere, 13(7): 2043-2049.

Schlosser E. 1997. Numerical simulation of fluctuations of Hintereisferner, Ötztal Alps, since AD 1850. Annals of Glaciology, 24: 199-202.

Shi Y F, Liu S Y, Ye B S, et al. 2008. Concise Glacier Inventory of China. Shanghai: Shanghai Popular Science Press, 22-31. (in Chinese)

Sun B, He M B, Zhang P, et al. 2003. Determination of ice thickness, subice topography and ice volume at Glacier No. 1 in the Tianshan, China, by ground penetrating radar. Chinese Journal of Polar Research, 15(1): 35-44. (in Chinese)

Sun M P, Liu S Y, Yao X J, et al. 2018. Glacier changes in the Qilian Mountains in the past half-century: Based on the revised First and Second Chinese Glacier Inventory. Journal of Geographical Sciences, 28(2): 206-220.

Wang N L, Pu J C. 2009. Ice thickness, sounded by ground penetrating radar, on the Bayi Glacier in the Qilian Mountains, China. Journal of Glaciology and Geocryology, 31(3): 431-435. (in Chinese)

Wang P Y, Li Z Q, Wang W B, et al. 2014a. Glacier volume calculation from ice-thickness data for mountain glaciers-A case study of glacier No. 4 of Sigong River over Mt. Bogda, eastern Tianshan, Central Asia. Journal of Earth Science, 25(2): 371378.

Wang P Y, Li Z Q, Jin S, et al. 2014b. Ice thickness, volume and subglacial topography of Urumqi Glacier No. 1, Tianshan Mountains, central Asia, by ground penetrating radar survey. Journal of Earth System Science, 123(3): 581-591.

Wang P Y, Li Z Q, Zhou P, et al. 2015. Recent changes of two selected glaciers in Hami Prefecture of eastern Xinjiang and their impact on water resources. Quaternary International, 358: 146-152.

Wang P Y, Li Z Q, Li H L, et al. 2016a. Recent Evolution in extent, thickness, and velocity of Haxilegen Glacier No. 51, Kuytun River Basin, Eastern Tianshan Mountains. Arctic, Antarctic, and Alpine Research, 48(2): 241-252.

Wang P Y, Li Z Q, Li H L, et al. 2016b. Analyses of recent observations of Urumqi Glacier No. 1, Chinese Tianshan Mountains. Environmental Earth Sciences, 75(8): 1-11.

Wang P Y, Li Z Q, Li H L, et al. 2017. Characteristics of a partially debris-covered glacier and its response to atmospheric warming in Mt. Tomor, Tien Shan, China. Global and Planetary Change, 159: 11-24.

Xing W C, Li Z Q, Zhang H, et al. 2017. Spatial-temporal variation of glacier resources in Chinese Tianshan Mountains since 1959. Acta Geographica Sinica, 72(9): 1594-1605. (in Chinese)

Xu C H, Li Z Q, Wang F T, et al. 2017. Using an ultra-long-range terrestrial laser scanner to monitor the net mass balance of Urumqi Glacier No. 1, eastern Tien Shan, China, at the monthly scale. Journal of Glaciology, 63(241): 792-802.

Yao X J, Liu S Y, Guo W Q, et al. 2012. Glacier change of Altay Mountain in China from 1960 to 2009—Based on the Second Glacier Inventory of China. Journal of Nature Resources, 17(10): 1734-1745. (in Chinese)

Zhang Y, Enomoto H, Ohata T, et al. 2016. Projections of glacier change in the Altai Mountains under twenty-first century climate scenarios. Climate Dynamics, 47(9-10): 2935-2953.

Zhu D Y, Tian L D, Wang J L, et al. 2014a. The Qiangtang Glacier No. 1 in the middle of the Tibetan Plateau: Depth sounded by using GPR and volume estimated. Journal of Glaciology and Geocryology, 36(2): 278-285. (in Chinese)

Zhu M L, Yao T D, Yang W, et al. 2014b. Ice volume and characteristics of sub-glacial topography of the Zhadang Glacier, Nyainqêntanglha Range. Journal of Glaciology and Geocryology, 36(2): 268-277. (in Chinese) 